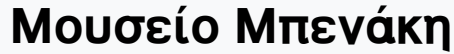

Tóp. 2 (2002)

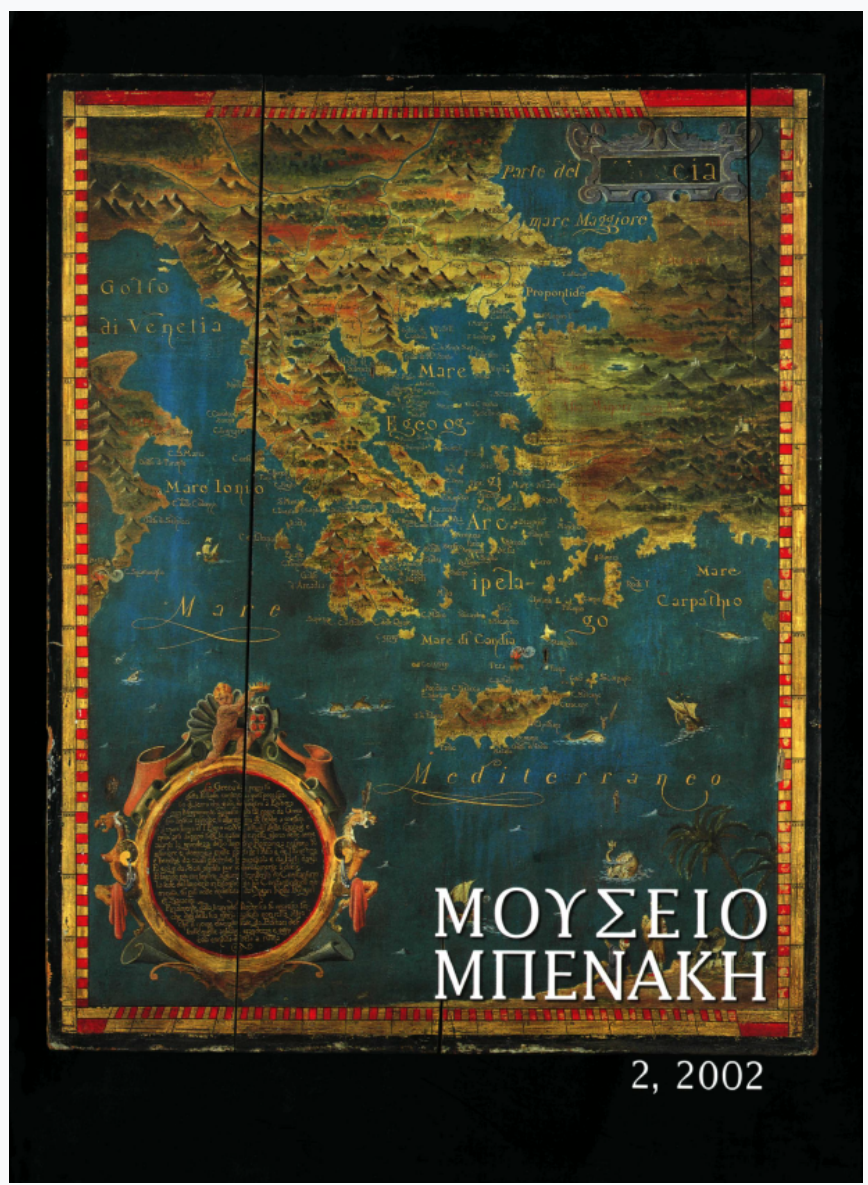

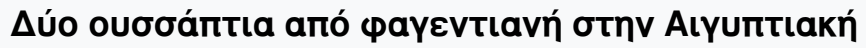

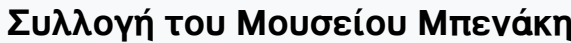

Amanda-Alice Maravelia

doi: $10.12681 /$ benaki.18185

Copyright $\odot$ 2018, Amanda-Alice Maravelia

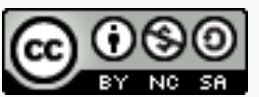

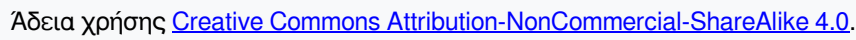

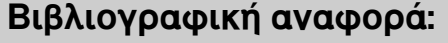

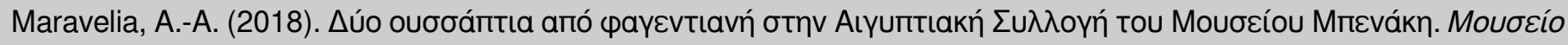
Мпєvákn, 2, 19-24. https://doi.org/10.12681/benaki.18185 


\section{Two Faience Shabtis from the Egyptian Collection at the Benaki Museum}

AMONG THE BENAKI MUSEUM'S superb collections of ancient and modern objects ${ }^{1}$ can be found three small collections of Egyptian antiquities, namely bone carvings, ${ }^{2}$ clay figurines ${ }^{3}$ and faience objects. ${ }^{4}$ The major part of the faience collection was donated by Lucas Benaki to the Museum between 1959 and 1974; the few inscribed pieces were acquired during the 1930s. The collection comprises about 140 pieces (more than $90 \%$ uninscribed), most of which date from the Ptolemaic and Greco-Roman Periods up to AD 300, although several pieces date from the New Kingdom (NK), Third Intermediate Period (TIP) and Late Period (LP). It includes objects of various kinds, among them funerary implements such as several amulets (mainly divinities), two funerary pectorals (one inscribed) and nine small shabtis (seven inscribed). Seven of these are on permanent loan from the private collection of Georgios Leotsakos.

Faience ${ }^{5}$ was a material used at various periods of history in the manufacture of many types of object, including beads, pectorals, statuettes, votive objects, steles, tiles, animal figurines, vases, jars, lamps, plates, bowls (Nunschale) and chalices bearing floral and/or zoomorphic decorations, as well as a vast number of amulets and shabtis. Faience was primarily valued for its latent symbolism, because it was regarded as a manifestation of the colour of the sky and of light, as is clear from its ancient Egyptian name, ${ }^{6} \underline{t} \underline{h n . t}$, which derives from the old stem $\underline{t h n}(i)$, meaning sparkle, be dazzling. Ancient Egyptians connected faience with the sun's regeneration from the Netherworld and the subsequent dazzling light, which was essential for the well-being of deceased humans in the afterlife. The bright green colour usually associated with this substance (although faience also appears in other colours) was related to the rebirth of everything in nature, alluding to an Osirian connotation. ${ }^{7}$

The use of shabtis by the Egyptians of antiquity is well attested and understood. ${ }^{8}$ They were funerary figurines, usually mummiform in appearance, which developed during the Middle Kingdom out of the funerary statuettes and models placed in the tombs of the Old Kingdom. A plausible etymology of their name (they were known as wšbty from the Late Period onwards) derives from the verb wšb(i), which means answer, respond. ${ }^{9}$ The purpose of these statuettes was to magically spare their owners from the menial corvée labour in the afterlife (at the Field of Reeds) by which deceased humans were required to produce their own food. Many shabtis are inscribed with a version of Utterance 6 from the Book of the Dead. ${ }^{10}$ The two faience shabtis studied here belong to the Museum's small but interesting Egyptian collection. The first of them was donated by Lucas Benakis during the late 1960s. The second is a recent acquisition, part of the permanent loan from G. Leotsakos. Both objects come with no information as to their provenance.

\section{B 21.830}

Typology: Class VIIIa2 / W21-H4-I5-B15-Tp7b

Date: Mid Dyn. XXI - Early Dyn. XXII

Colour: Sky-Blue Paste (bearing magenta-violet decoration)

Dimensions: $9.5 \mathrm{~cm}$ (max height)

This is a faience shabti in a mediocre to bad state 
of preservation, bearing an unframed column of short illegible inscription on the front (figs 1-2). Its colour is sky-blue (or blue-turquoise), and its dimensions are as follows: H. $9.5 \mathrm{~cm}$, L. $3.9 \mathrm{~cm}$, B. 2.1 (base) $-1.5 \mathrm{~cm}$. The paste is damaged and missing in several places (especially head, face, body and thighs). At the bottom of the base and on the back there are places showing patina. The deceased is portrayed wearing the tripartite wig (a TIP striated lappet wig), a considerable part of which is now damaged. The striation is depicted with magenta-violet paint (see below), which has disappeared on the right side part of the wig. The side parts of the wig continue along the forearms, curve slightly and reach down to the palms of the deceased, running almost parallel to the agricultural tools he is holding. The face is almost totally damaged and the left ear is broken. The right ear is extant and protrudes over the right side part of the wig. ${ }^{11}$ Few traces of the paste remain on the face. There are no different colour paste inlays on the object. The deceased holds two $m r$-hoes in his hands (or bुbs-hoes, Gardiner's U6), painted on the sky-blue paste with a magenta-violet colour deriving from manganese oxide $(\mathrm{MnO})$. Only the hands and part of the forearms protrude from the chest and the upper part of the body. The thickness of the body hardly varies from the shoulders to the toes, although it becomes somewhat narrower near the feet. On the back of the figure is an elaborate rectangular bag painted with the same magenta-violet colour, depicted as attached to the wig by straps (which are also painted in the same way).

The shabti originally carried a short hieroglyphic inscription running down from the chest to the feet as an unframed column, which is now illegible and almost completely destroyed. The last and only extant symbol looks like the $\underline{d} d$-hieroglyph (Gardiner's R11) and is situated near the feet. The object has no pillar on its flat back and cannot stand upright. It appears to be of mediocre craftsmanship, and was most probably mass produced in a funerary workshop for use at a burial. On the basis of stylistic similarities this object should be dated to Dynasty XXI (c. 1070-945 BC) or slightly later, but in any case not later than the beginning of Dynasty XXII of the TIP (terminus a quo c. 1000 BC, terminus ad quem c. $900 \mathrm{BC}$ ). Indeed, the thick-set body of the object is consistent with shabti models cur-
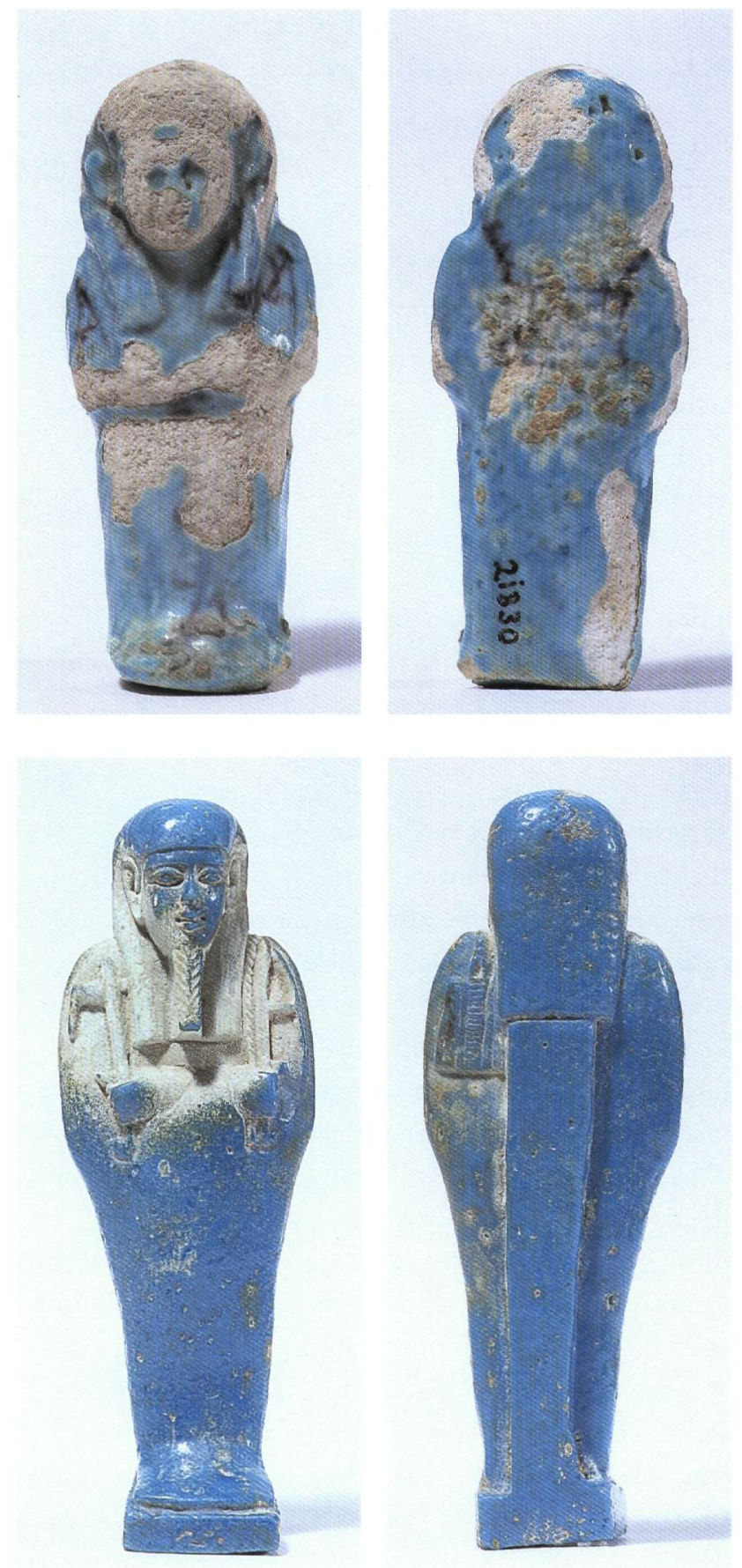

Fig. 1-2. The shabti 21. 830, donation of L. Benakis (photo: K. Manolis).

Fig. 3-4. The shabti B/L 83 part of the permanent loan from G. Leotsakos (photo: K. Manolis). 
rent at the end of Dynasty XXI or even the beginning of Dynasty XXII, mainly in the Theban area.

\section{B/L 83}

Typology: Class X1a1 / W36-H4-I8-B28-Tp0

Date: Dyn. XXX

Colour: Blue

Dimensions: $12.2 \mathrm{~cm}$ (max height)

This is an uninscribed faience shabti in an excellent state of preservation (figs 3-4). Its colour is blue, and its dimensions are: H. $12.2 \mathrm{~cm}, \mathrm{~L} .4 .2 \mathrm{~cm}, \mathrm{~B}$ (mean) 2.5 $\mathrm{cm}$ (the sides of the base, which, unlike that of the previous piece, is well and clearly defined, are $2.8 \mathrm{~cm}, 2.1$ $\mathrm{cm}$ and $2.5 \mathrm{~cm}$, while its maximum height is $0.9 \mathrm{~cm}$ ). The base is separated from the body of the statuette, like a low pedestal. The deceased is depicted wearing the tripartite wig (in this case the Saite common plain lappet wig), which is well preserved. The face is almost perfectly preserved, the eyes have the characteristic Egyptian stare -as if gazing on eternity- and both ears are extant and protrude over the wig. The eyes, lips, and nose are very prominent and well sculpted. However, part of the face and almost the whole of the chest are decolorized and have a white appearance, having lost their blue paste coating; the same applies to the agricultural tools, but not to the hands. The deceased wears the divine beard, an indispensable feature of his $s^{e} h$-status, ${ }^{12}$ as is the mummified representation of his body which alludes to its post mortem essence of purity and virtual union with the divine. The beard itself is plaited, runs parallel to the side parts of the wig and ends at the same height as these. The deceased holds a $m r$-hoe (or bbs-hoe, Gardiner's U6) and a cord in his right hand, and a pick (without cross bar) in his left hand. The rope holding the agricultural bag (a Saite trapezoid bag with crossed oblique pattern and loop) runs parallel to the hoe on the left side of the body, then over and round the back of the shoulder to keep the bag in place. The tools are incised in high relief, as are the beard and the facial features of the deceased. Only the hands and part of the forearms protrude from the chest and the upper part of the body is more voluminous in shape, reminiscent of the swollen type of coffin characteristic of the second half of the LP. ${ }^{13}$ The shabti has a pillar on its back, which starts where the wig ends and stops at the base, but it cannot stand upright. The whole composition and style evoke official undertones. On the basis of stylistic similarities this object can be dated to Dynasty XXX (380-343 BC); indeed, the agricultural tools sculpted in high relief are reminiscent of the style of shabti models during that period. During the reign of this last Egyptian (autochthonous) Dynasty, the Nectanebos ${ }^{14}$ presented the temples with rich offerings, tried to reconstruct Egypt and invested the artistic style with a pharaonic nuance which is evident in this shabti.

A large number of shabtis similar to those described above can be found scattered all over the world in various Egyptian collections. Since nothing is known of the context of the objects presented here, it would appear somewhat superfluous to attempt any specific comparisons, since this would reveal neither their actual provenance nor the exact date of their production.

Dr Amanda-Alice Maravelia

Egyptologist/Archaeoastronomer

Université de Limoges / Athens

e-mail:a_maravelia@hotmail.com

\section{NOTES}

* I should like to thank Prof. Dr A. Delivorrias for permitting and encouraging the study and publication of these faience shabtis. Warm thanks are also due to those in charge of the Museum's Egyptian Collection (Mrs E. Papageorgiou and Mrs A. Ziva) for their kind assistance. I am also grateful to Prof. Dr. W. van Haarlem and Dr. J.-L. Chappaz for confirming the dating and for some comments on typology.
1. D. Fotopoulos, A. Delivorrias, Greece at the Benaki Museum (Athens 1997) 130-33, for a few of the Egyptian objects on display. For an introduction to the Egyptian Collections at the Benaki Museum, see also A.-A. Maravelia, "Oтı $\pi \lambda \varepsilon \tilde{\varepsilon} \sigma \tau a$

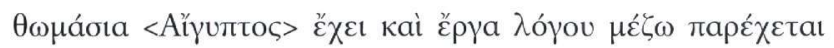

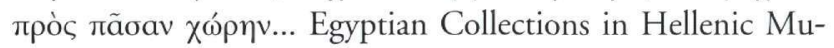
seums: A Brief History and Some Pieces, in: A.-A. Maravelia 
(ed.), Ancient Egypt and Antique Europe: Two Parts of the Mediterranean World. Papers from Session 30, held at the 7th Annual Meeting of the EAA in Esslingen 2001 (BAR S1052, Oxford 2002) 15-29 esp. 17-18 and 21-22.

2. L. Marangou, Bone Carvings from Egypt, I: Graeco-Roman Period (Tübingen-Athens 1976).

3. S. Pingiatoglou, The Coroplastic of Egypt during the Hellenistic and Roman Eras, 300 BC-AD 400 (Athens 1993).

4. A.-A. Maravelia, Ancient Egyptian Inscribed Faience Objects from the Benaki Museum in Athens, 1, JNES 61,2 (2002) 81-109.

5. See, for instance P. T. Nicholson, Egyptian Faience and Glass (UK, Shire Egyptology 19, 1993). A modern book on this topic, featuring many faience pieces and referring to recent articles, is F. D. Friedman (ed.), Gifts of the Nile: Ancient Egyptian Faience (London 1998). For an interesting collection of several types of faience items, E. Riefstahl, Ancient Egyptian Glass and Glazes in the Brooklyn Museum (Brooklyn Museum, Wilbour Monographs 1, New York 1978); see also A. Kaczmarczyk, R. E. M. Hedges, Ancient Egyptian Faience: An Analytical Survey of Egyptian Faience from Predynastic to Roman Times (Warminster 1983), and LÄII (1977) 138-42 s.v. Fayence. The standard discussion of ancient Egyptian faience and glazing is found in A. Lucas, Ancient Egyptian Materials and Industries (London 1962 ). Cf. P. T. Nicholson, E. J. Peltenburg, Egyptian Faience, in: P. T. Nicholson, I. Shaw (eds), Ancient Egyptian Materials and Technology (Cambridge 1999) 177-94. Cf. also the article by P. Vandiver, W. D. Kingery, Egyptian Faience: The First High-Tech Ceramic, in: W. D. Kingery (ed.), Ceramics and Civilization III (Columbus-Ohio 1987). Finally, see J. V. Noble, The Technique of Egyptian Faience, AJA 73 (1969) 435-39. For the various faience techniques and kyanos, see also M. S. Tite, Egyptian Blue, Faience and Related Materials: Technological Investigations, in: R. E. Jones, H. W. Catling (eds), Science in Archaeology (Athens 1986) 39-41; see also M. S. Tite, I. C. Freestone, M. Bimson, Egyptian Faience: An Investigation of the Methods of Production, Archaeometry 25,1 (1983) 17 27. For a concise general introduction to the techniques and history of Egyptian faience, see P. T. Nicholson, Faience, in: D. B. Redford (ed.), The Oxford Encyclopedia of Ancient Egypt I (Oxford 2001) 491-96.

6. A. H. Gardiner, Egyptian Grammar: Being an Introduction to the Study of Hieroglyphs (Oxford 1988 $=10$ th Impression) 505 .

7. R. H. Wilkinson, Symbol and Magic in Egyptian Art (Lon- don 1994), provides a sound basis for this discussion. For the symbolism of colour, see for example Wilkinson (op. cit.) 10425 . On the various colour nuances of faience, $\mathrm{cf}$. G. Posener et al. (eds), Dictionnaire de la Civilisation Égytienne (1992) 110. See also I. Shaw, P. T. Nicholson (eds), British Museum Dictionary of Ancient Egypt (Cairo 1996) 95-96 (hereafter BMD).

8. The standard discussion of ancient Egyptian shabtis is found in H. D. Schneider, Shabtis: An Introduction to the History of Ancient Egyptian Funerary Statuettes with a Catalogue of the Collection of Shabtis in the National Museum of Antiquities at Leiden I-II (Collections of the National Museum of Antiquities at Leiden II, Leiden 1977). See also W. M. van Haarlem (ed.), Corpus Antiquitatum Aegyptiacarum: Allard Pierson Museum I-III (Amsterdam 1986-95); J.-F. Aubert, L. Aubert, Statuettes Égytiennes: Chaouabtis, Ouchebtis (Paris 1974). Cf. also W. M. F. Petrie, Shabtis (Warminster 1974²); E. T. White, Some Remarks on the Sepulchral Figures usually called Ushabti, PSBA 18 (1896) 138-45 pls 1-10.

9. See for instance $B M D, 266-67$, which contains more discussion on shabtis. See also L̈̈ VI (1986) 896-900 s.v. Uschebti.

10. See for instance: R. O. Faulkner, O. Goelet, The Egyptian Book of the Dead: The Book of going forth by Day. Being the Papyrus of Ani (San Francisco 1998') 101; R. O. Faulkner, The Ancient Egyptian Book of the Dead (London 19934) 36-37. See also P. Barguet, Le Livre des Morts des Anciens Égytiens (Paris 1967) 42. This spell is certainly older than the NK, since it is also attested in the Coffin Texts (cf. Utterance 472). On this topic, see A. de Buck, The Egyptian Coffin Texts I-VII (Chicago 1935-1961); R. O. Faulkner, The Ancient Egyptian Coffin Texts I-III (Warminster 1973-1978) esp. II 106-07.

11. On the use of wigs, see for instance BMD, 117-18.

12. For this, see Schneider I (n. 8) 65-67. This hybrid entity was considered to partake of both the divine and human hypostases. The $s^{r} b$-status was achieved through a religiously correct burial, at which the corpse was mummified and provided with a mummy mask and a special coffin in order to attain the bliss of incorruptibility in the hereafter.

13. See for instance M. Jørgensen, Catalogue EGYPT III: Coffins, Mummy Adornments and Mummies from the TIP, LP, Ptolemaic and Roman Periods (Copenhagen 2001) 18.

14. See for instance N. Grimal, A History of Ancient Egypt (Oxford 1992²) 375-81. 


\section{AMANTA-A $\Lambda$ KH MAPABE $\Lambda$ IA}

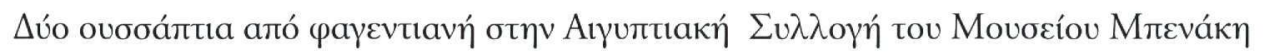

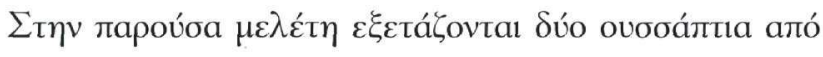

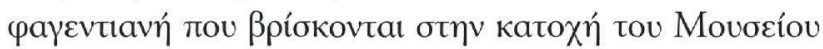

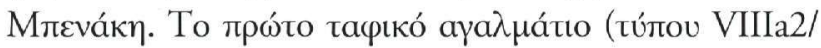

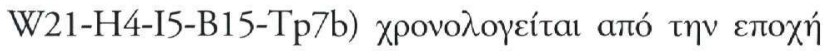

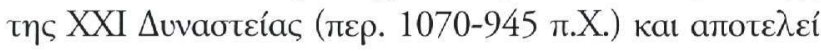

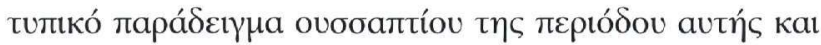

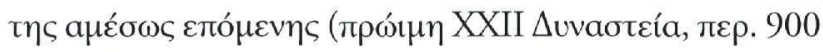

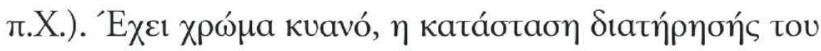

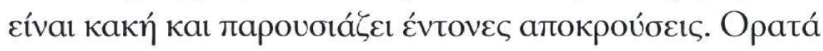

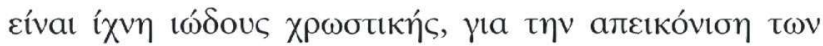

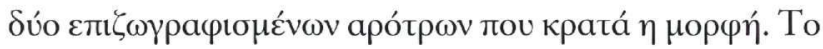

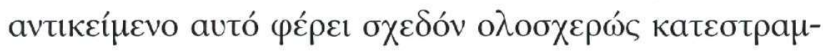

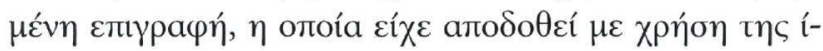

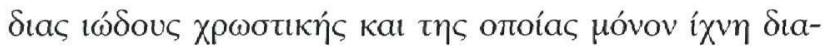

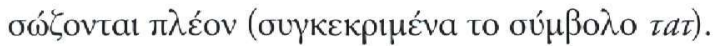

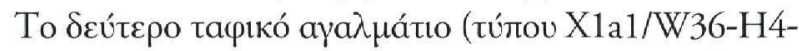

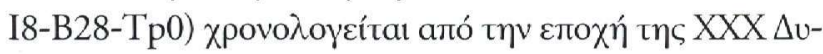

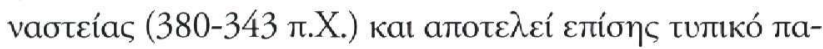

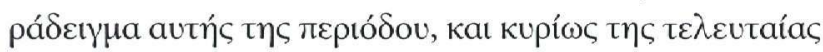

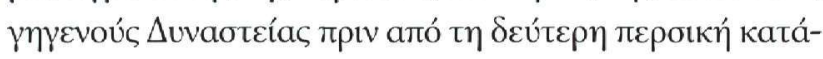

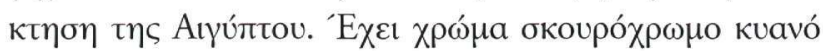

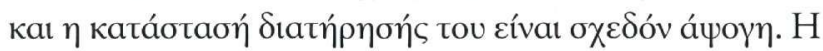

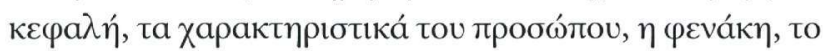

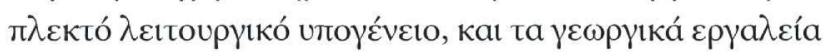

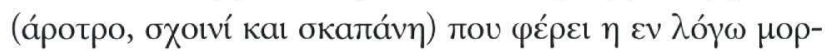

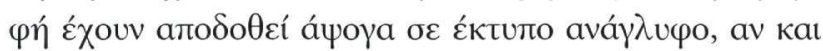

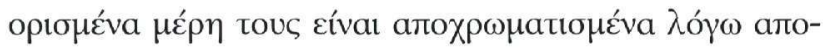

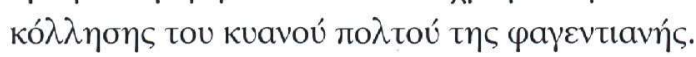

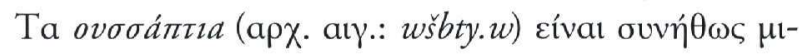

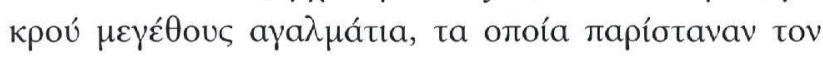

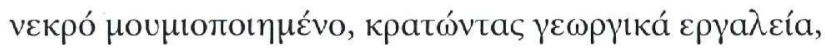

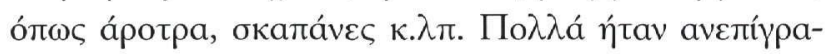

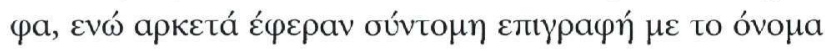

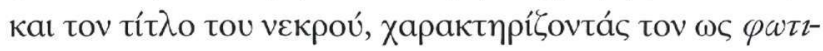

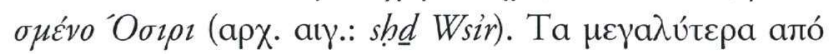
autá ع́

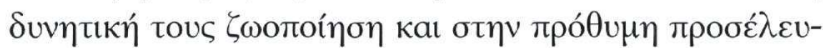

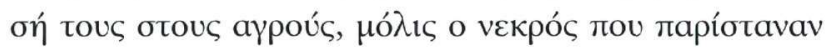

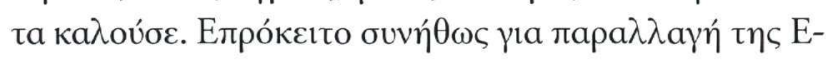

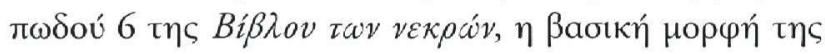

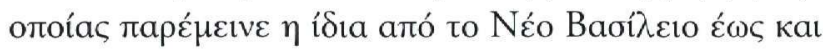

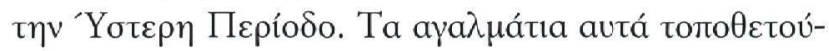

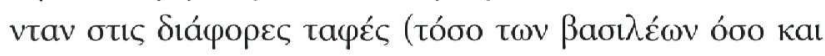

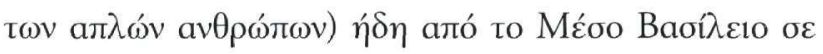

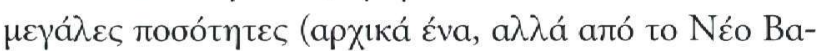
бí̀

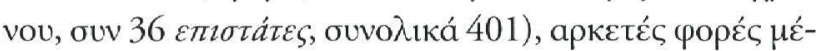

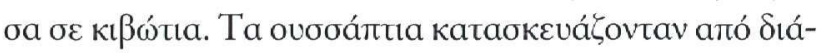

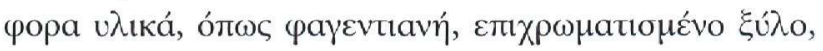

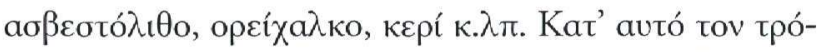

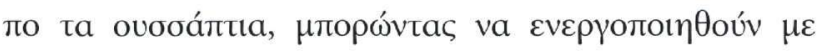

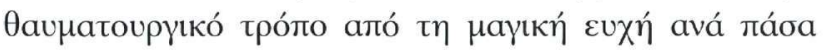

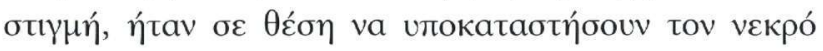

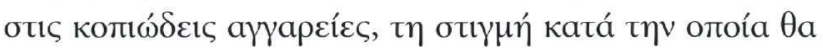

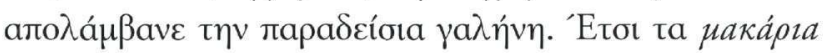

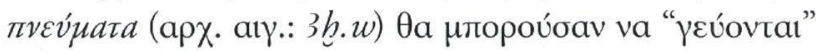

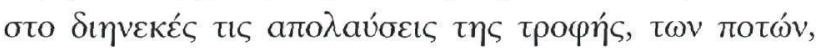

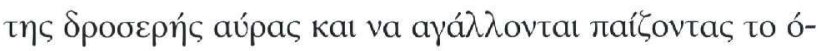

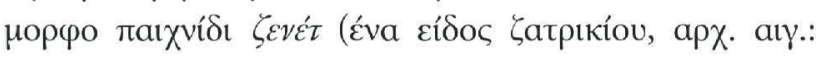

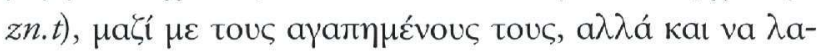

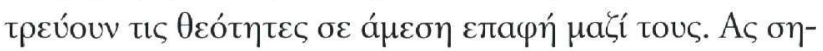

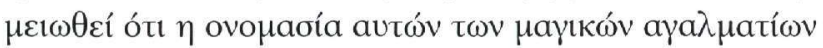

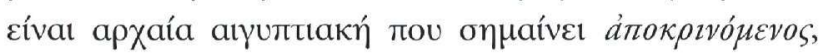

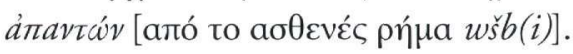

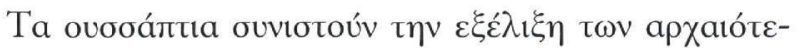

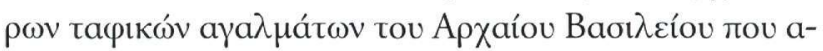

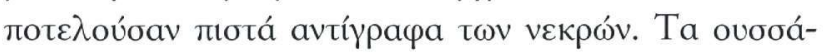

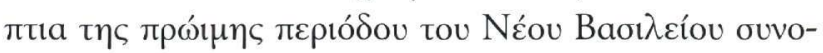

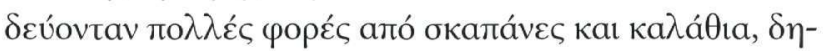

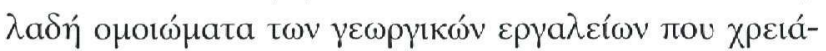

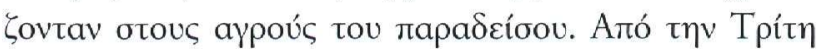

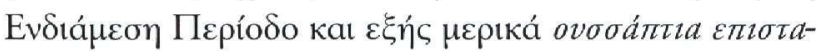

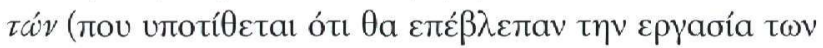

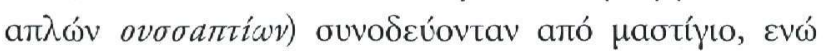

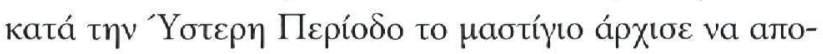

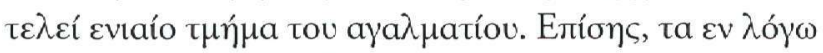

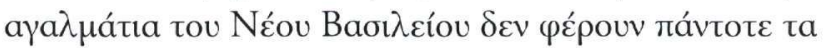

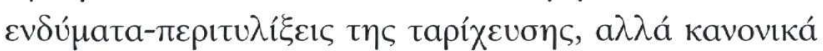

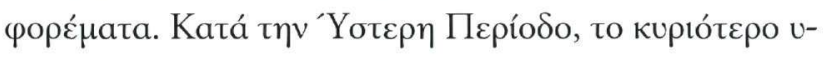

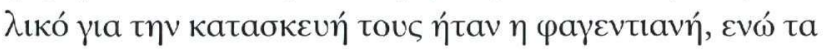

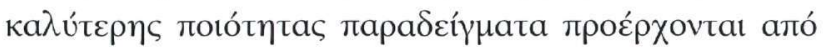

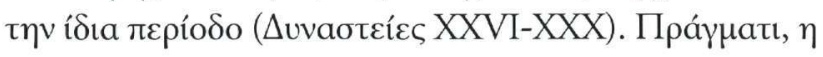

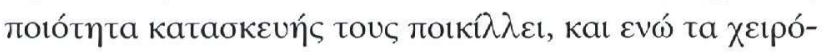

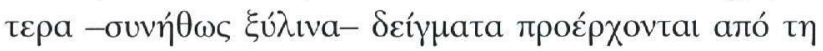

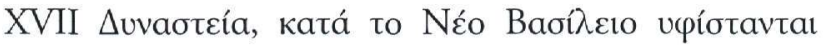

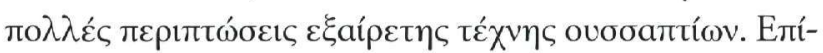




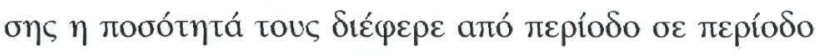

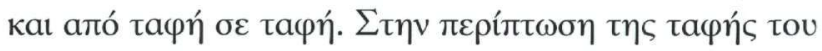

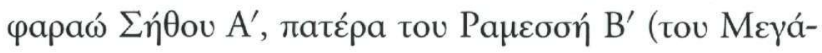

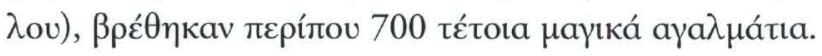

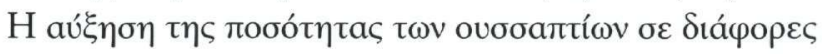

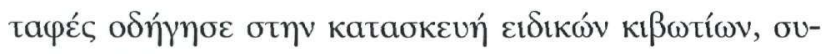

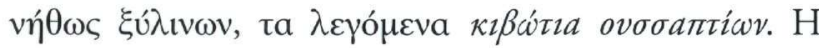

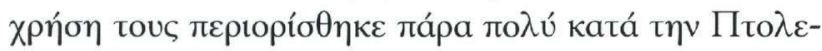

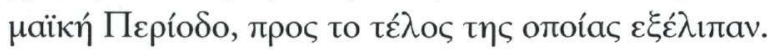

